\title{
Integrated Grazing and Prescribed Fire Restoration Strategies in a Mesquite Savanna: II. Fire Behavior and Mesquite Landscape Cover Responses
}

\author{
R. J. Ansley, ${ }^{1}$ W. E. Pinchak, ${ }^{1}$ W. R. Teague, ${ }^{1}$ B. A. Kramp, ${ }^{2}$ D. L. Jones, ${ }^{3}$ and K. Barnett ${ }^{3}$ \\ Authors are ${ }^{1}$ Professors, ${ }^{2}$ Senior Research Associate, and ${ }^{3}$ Research Technicians, Texas AgriLife Research, Vernon, TX 76385, USA.
}

\begin{abstract}
Prescribed fire is used to reduce the rate of woody plant encroachment in grassland ecosystems. However, fire is challenging to apply in continuously grazed pastures because of the difficulty in accumulating sufficient herbaceous fine fuel for fire. We evaluated the potential of rotationally grazing cattle in fenced paddocks as a means to defer grazing in selected paddocks to provide fine fuel for burning. Canopy cover changes from 1995 to 2000 of the dominant woody plant, honey mesquite (Prosopis glandulosa Torr.), were compared in three landscape-scale grazing and mesquite treatment restoration strategies: 4-paddock, 1herd with fire $(4: 1 \mathrm{~F}), 8$-paddock, 1-herd with fire $(8: 1 \mathrm{~F})$, and $4: 1$ with fire or aerial application of $0.28 \mathrm{~kg} \cdot \mathrm{ha}^{-1}$ clopyralid $+0.28 \mathrm{~kg} \cdot \mathrm{ha}^{-1}$ triclopyr herbicide $(4: 1 \mathrm{~F} / \mathrm{H})$, and a continuously grazed control with mesquite untreated $(\mathrm{CU})$. Prescribed burning took place in late winter (February-March). Droughts limited burning during the 5-yr period to half the paddocks in the 4:1F and 8:1F strategies, and one paddock in each 4:1F/H strategy. Mesquite cover was measured using digitized aerial images in 1995 (pretreatment) and 2000. Mesquite cover was reduced in all paddocks that received prescribed fire, independent of grazing strategy. Net change in mesquite cover in each strategy, scaled to account for soil types and paddock sizes, was $+34 \%,+15 \%,+5 \%$, and $-41 \%$ in the $\mathrm{CU}, 4: 1 \mathrm{~F}, 8: 1 \mathrm{~F}$, and $4: 1 \mathrm{~F} / \mathrm{H}$ strategies, respectively. Thus, rotational grazing and fire strategies slowed the rate of mesquite cover increase but did not reduce it. Fire was more effective in the $8: 1 \mathrm{~F}$ than the 4:1F strategy during drought because a smaller portion of the total management area $(12.5 \%$ vs. $25 \%)$ could be isolated to accumulate fine fuel for fire. Herbaceous fine fuel and relative humidity were the most important factors in determining mesquite top-kill by fire.
\end{abstract}

\section{Resumen}

Las quemas prescritas se utilizan para reducir la tasa de invasión de plantas leñosas en ecosistemas de pastizales. Sin embargo, es un reto la aplicación de las quemas a potreros continuamente pastoreados, debido a la dificultad para que acumulen suficiente combustible fino para llevar a cabo la quema. Evaluamos el potencial del uso del pastoreo rotacional con ganado utilizando potreros cercados como un medio de aplazar el pastoreo en potreros seleccionados para proporcionar combustible fino para la quema. Se compararon los cambios de la cubierta aérea de la especie leñosa dominante, mezquite (Prosopis glandulosa Torr.), bajo tres tratamientos de pastoreo y estrategias de restauración: 4-potreros, 1-hato y quemas (4:1Q), 8-potreros, 1-hato y quemas (8:1Q), y $4: 1$ con quemas o aplicación aérea de $0.28 \mathrm{~kg} \cdot \mathrm{ha}^{-1}$ de clopyralid + de $0.28 \mathrm{~kg} \cdot \mathrm{ha}^{-1}$ de triclopyr $(4: 1 \mathrm{Q} / \mathrm{H})$, y un potrero con pastoreo contínuo como tratamiento control sin tratamiento al mezquite (CU). Las quemas prescritas se llevaron a cabo al final del invierno (Febrero-Marzo). Las sequías limitaron las quemas durante un periodo de 5 años a la mitad de los potreros en los tratamientos $4: 1 \mathrm{Q}$ y $8: 1 \mathrm{Q}$, y en un potrero en cada uno de los tratamientos $4: 1 \mathrm{Q} / \mathrm{H}$. La cobertura del mezquite se midió a través de imágenes aéreas digitalizadas en 1995 (antes de los tratamientos) y durante 2000. La cobertura del mezquite se redujo en todos los potreros que recibieron fuego, independientemente de la estrategia de pastoreo. El cambio neto en la cubierta del mezquite en cada estrategia, tomando en cuenta los tipos de suelos y tamaño de los potreros fue $+34 \%,+15 \%,+5 \%$, y $-41 \%$ en el CU, y para las estrategias 4:1Q, 8:1Q, y 4: 1Q/H, respectivamente. Por lo tanto, las estrategias del pastoreo y uso del fuego redujeron la tasa de aumento de la cobertura del mezquite pero no la redujo. El uso del fuego fue más efectivo en 8:1Q que en la estrategia de 4:1Q durante la sequía debido a que una zona menor del área total de manejo $(12.5 \%$ vs. $25 \%)$ podría aislarse de forma que acumule combustible fino para llevar a cabo la quema. El combustible fino de las herbáceas y la humedad relativa fueron los factores en determinar la muerte superior del mezquite con el uso del fuego.

Key Words: aerial imagery, brush management, cattle, grazing management, Prosopis glandulosa, remote sensing

Funding was provided by the US Department of Agriculture, National Research Initiative Competitive Grants Program Agricultural Systems Grants 94-37211-1172 and 98-35108-6491; the E. Paul and Helen Buck Waggoner Foundation, Inc.; Dow AgroSciences, Indianapolis, IN; the North Texas Brush Control Association, Albany, TX; and Texas AgriLife Research (Hatch Project 8307). The W. T. Waggoner Estate, Vernon, TX, provided land area, facilities, and cattle for the project.

Correspondence: R. James Ansley, Texas AgriLife Research, PO Box 1658, 11708 Hwy 70 South, Vernon, TX 76835, USA. Email: r-ansley@tamu.edu

Manuscript received 21 July 2008; manuscript accepted 4 May 2009.

\section{INTRODUCTION}

Encroachment of woody plants into arid and semiarid grasslands has occurred on a world-wide scale (Archer et al. 1995; Van Auken 2000; Ansley et al. 2001; Asner et al. 2003). Causal factors include reduced fire frequency, livestock overgrazing, increased seed distribution via livestock consumption and fecal deposition, and possibly increased $\mathrm{CO}_{2}$ levels that 
favor growth of $\mathrm{C}_{3}$ shrubs over $\mathrm{C}_{4}$ grasses (Blackburn and Tueller 1970; Archer et al. 1995; Kramp et al. 1998). Woody plants often are a threat to grassland ecosystems and the livestock industry because they reduce herbaceous production (Bedunah and Sosebee 1984; Walker et al. 1986), increase bare ground and erosion potential (Teague and Dowhower 2003; Ansley et al. 2006), and interfere with livestock handling (Scifres 1980).

Prescribed fire is an attractive option for reducing woody plant dominance on grasslands because it is less costly than other options such as chemical and/or mechanical applications (Wright and Bailey 1982; Scifres and Hamilton 1993). However, for fire to be an effective method for woody plant suppression on livestock-grazed lands, a grazing management strategy must be employed that allows for accumulation of the herbaceous biomass (otherwise called "fine fuel") necessary to fuel fire (Teague et al. 1997; Fuhlendorf and Engle 2004). Moreover, for woody species that are usually only "top-killed" by fire and that resprout following a topkill disturbance, a grazing management strategy must allow for frequent planned burning to maintain suppression of the woody regrowth.

In the mixed-grass prairie of the southern Great Plains in the United States, grass production in normal or drought years is not adequate under moderate or high cattle stocking rates in continuously grazed strategies to carry a fire of sufficient intensity to suppress woody vegetation. One usually must wait for an atypically wet year to accumulate enough herbaceous fine fuel. However, even under these conditions, cattle often concentrate on grazing the $\mathrm{C}_{4}$ midgrasses (Pinchak et al. 1990) that provide the most abundant fuel for fire. The degree to which this process occurs is dependent on stocking rate, landscape heterogeneity, and degradation of the site (Teague and Dowhower 2003; Fuhlendorf and Engle 2004; Briske et al. 2008).

Prescribed burning might be more easily incorporated into these mixed-grass ecosystems using deferred or rotational grazing to manage fine fuel loads. Typically, a ranch is subdivided by fencing into paddocks and the entire herd that is stocked to the carrying capacity of the ranch is moved from one paddock to another. One or more of these paddocks can be deferred from grazing for a period of time to accumulate sufficient grass fuel for fire. The grazing deferral period required to accumulate fuel within a paddock (or paddocks) targeted for burning is thus "internalized" by moving the herd that is stocked for the total carrying capacity of the management unit among the other paddocks (Teague et al. 1997).

Alternatively, woody plant suppression or control could be accomplished through chemical or mechanical treatment (Ansley et al. 2004; McGinty 2004). This is attractive especially in ecosystems where herbaceous production is not adequate to support a fire that would suppress woody plants, or in situations where the woody overstory is so dominant that it would suppress grass growth even in the absence of grazing (Ansley et al. 2006). However, application of these treatments on large land areas is often cost-prohibitive. Thus, there is a need for grazing management strategies that facilitate application of repeated fires to sufficiently suppress the woody component.
Here, we evaluate the utility of landscape-scale grazing strategies to provide sufficient herbaceous fine fuel for prescribed fire to suppress mature honey mesquite (Prosopis glandulosa Torr.). Our study area was dominated by mature (2-4 m tall) mesquite trees of moderate $(15-30 \%)$ canopy cover. Long-term continuous cattle grazing, coupled with competition from mesquite, had weakened the $\mathrm{C}_{4}$ midgrass component of the grass community. Thus, our challenge was to accumulate enough herbaceous fine fuel in targeted paddocks using rotational grazing and deferment, knowing that much of the herbaceous community was dominated by the less productive $\mathrm{C}_{3}$ midgrasses and $\mathrm{C}_{4}$ short grasses and that mesquite size, density, and cover were near the point where they would exert a strong negative effect on grass production even in the absence of grazing (Ansley et al. 2004). With these constraints, maximum herbaceous production under normal precipitation and deferment for one growing season might be $2000-3000 \mathrm{~kg} \cdot \mathrm{ha}^{-1}$ on deeper soils and half that on shallow soils. These fine fuel amounts likely would have variable effects on mature mesquite (Ansley et al. 1998); however, repeated fires should eventually top-kill most mesquite (Ansley and Jacoby 1998). Specific study objectives were 1) to compare the effectiveness of a 4-paddock, 1 herd (4:1) vs. an 8-paddock, 1 herd $(8: 1)$ rotation strategy for facilitating use of fire to suppress mesquite; 2) to compare these responses on deep and shallow soil types; 3 ) to compare the effectiveness, with respect to mesquite suppression, of these fire-based strategies to a strategy where mesquite was treated with herbicides; and 4) quantify the relationships between weather or fine fuel during the fire and mesquite top-kill by fire for the each of the prescribed fires we conducted. Our assumption was that weather and fine fuel affected fire intensity, which in turn would affect mesquite top-kill (Trollope and Tainton 1986; Britton and Wright 1971; Ansley et al. 1998). The focus of this study was on the measurement of landscape-scale changes in mesquite cover using aerial images. Two other companion papers measured herbaceous vegetation (Teague et al. 2010) and cattle (Pinchak et al. 2010) responses within these strategies.

\section{METHODS}

\section{Site Description}

The study was conducted on a 14400 -ha portion of the W. T. Waggoner Estate termed the "Kite Camp" $18 \mathrm{~km}$ southwest of Electra in north-central Texas (lat 33 $53^{\prime} \mathrm{N}$, long $99^{\circ} 03^{\prime} \mathrm{W}$; elevation 335-400 m; Teague et al. 1997; Asner et al. 2003). The climate is continental with an average 220 frost-free growing days. The $30-y r$ mean annual precipitation is $636 \mathrm{~mm}$, bimodally distributed with peaks in May and September. Mean annual temperature is $17^{\circ} \mathrm{C}$. Prior to treatment mesquite trees (aerial cover 15-20\%) dominated the vegetation matrix on bottomlands and clay loam sites. The herbaceous layer consists of a mixture of $\mathrm{C}_{3}$ and $\mathrm{C}_{4}$ perennial grasses. The main growth period for $\mathrm{C}_{4}$ grasses is April-September. Main growth periods for $\mathrm{C}_{3}$ grasses are February-May and September-October. The dominant $\mathrm{C}_{3}$ grass is the midgrass, Texas wintergrass (Nassella leucotricha [Trin. \& Rupr.] Pohl). Primary $\mathrm{C}_{4}$ grasses include shortgrass buffalograss (Bouteloua dactyloides [Nutt.] J. T. 
Columbus), and midgrasses, sideoats grama (Bouteloua curtipendula [Michx.] Torr.), silver bluestem (Bothriochloa laguroides [DC.] Herter), meadow dropseed (Sporobolus compositus [Poir.] Merr.), and vine mesquite (Panicum obtusum Kunth). The $\mathrm{C}_{3}$ annual Japanese bromegrass (Bromus japonicus Thunb. ex Murr.) is common. Prickly pear cactus (Opuntia phaeacantha Engelm.) ranges from $1 \%$ to $10 \%$ canopy cover. Nomenclature follows US Department of Agriculture-Natural Resources Conservation Service (2009). Soils are variable with a mixture of shallow clays ( $3 \%$ to $8 \%$ slopes), moderately deep clay loams ( $1 \%$ to $3 \%$ slopes), and deep loamy bottomlands in riparian zones $(0 \%$ to $1 \%$ slopes; US Department of Agriculture-Soil Conservation Service 1962). Mesquite size, density, and cover were greatest on the clay loam soils.

\section{Grazing, Fire, and Herbicide Strategies}

The experiment consisted of four ranch-scale grazing management and mesquite treatment strategies (hereafter referred to as "strategies") with two replicates per strategy (replicate size range: 1278-2162 ha). Initially, strategies were 1) a 4paddock, 1-herd rotation where one paddock was burned each year $(4: 1 \mathrm{~F}) ; 2)$ an 8 -paddock, 1-herd rotation where two paddocks were burned each year $(8: 1 \mathrm{~F}) ; 3)$ a 4-paddock, 3-herd rotation where one paddock was burned each year $(4: 3 \mathrm{~F})$; and 4) a continuously-grazed control with mesquite left untreated (CU; Teague et al. 1997). Thus, a total of 34 paddocks were involved in the study $[(1+4+4+8) \times 2$ reps $]$. The $4: 3 \mathrm{~F}$ strategy was later changed to a combined fire or herbicide treatment as explained below.

Livestock were managed in each strategy as a cow-calf operation (Hereford breed). Cattle stocking rates were maintained at similar levels within years in all strategies throughout the study and were initially set at $7.5 \mathrm{ha} \cdot$ animal unit ${ }^{-1} \cdot \mathrm{yr}^{-1}$ (ha $\cdot$ AUY $^{-1}$ ) in 1995, based on recommendations from the local Natural Resources Conservation Service office. Rates were reduced to $11-12 \mathrm{ha} \cdot \mathrm{AUY}^{-1}$ in 1997-1999 and $15 \mathrm{ha} \cdot$ $\mathrm{AUY}^{-1}$ in 2000 following severe droughts. Animal performance responses are available in Pinchak et al. (2010).

The initial woody plant management goal in the fire-based strategies was to burn a different $25 \%$ of the area of each strategy each year (e.g., 1 paddock in each 4-paddock strategy and 2 paddocks in each 8-paddock strategy) with high-intensity winter (January-March) fires to maximize mesquite top-kill. Fires were conducted as headfires usually with a southwest wind and were burned into preburned "blacklines" on downwind sides of each paddock. Blacklines were created by cutting parallel dozer lines, $60 \mathrm{~m}$ apart, on the north and east sides of each paddock and burning between the lines several days or weeks prior to headfire ignition using the "strip-head" method (Wright and Bailey 1982).

To accumulate herbaceous fuel in the paddock(s) to be burned, cattle were rotationally grazed on the remaining paddocks within each strategy for 4 to 6 mo without a reduction in strategy-level stocking rate. Thus, costs of deferral were internalized and cattle herds were contained within each strategy replicate. Fire was to be used when average or aboveaverage precipitation resulted in sufficient fine fuel to suppress mesquite. Because mesquite encroachment had degraded the herbaceous community to the point where it was unrealistic to
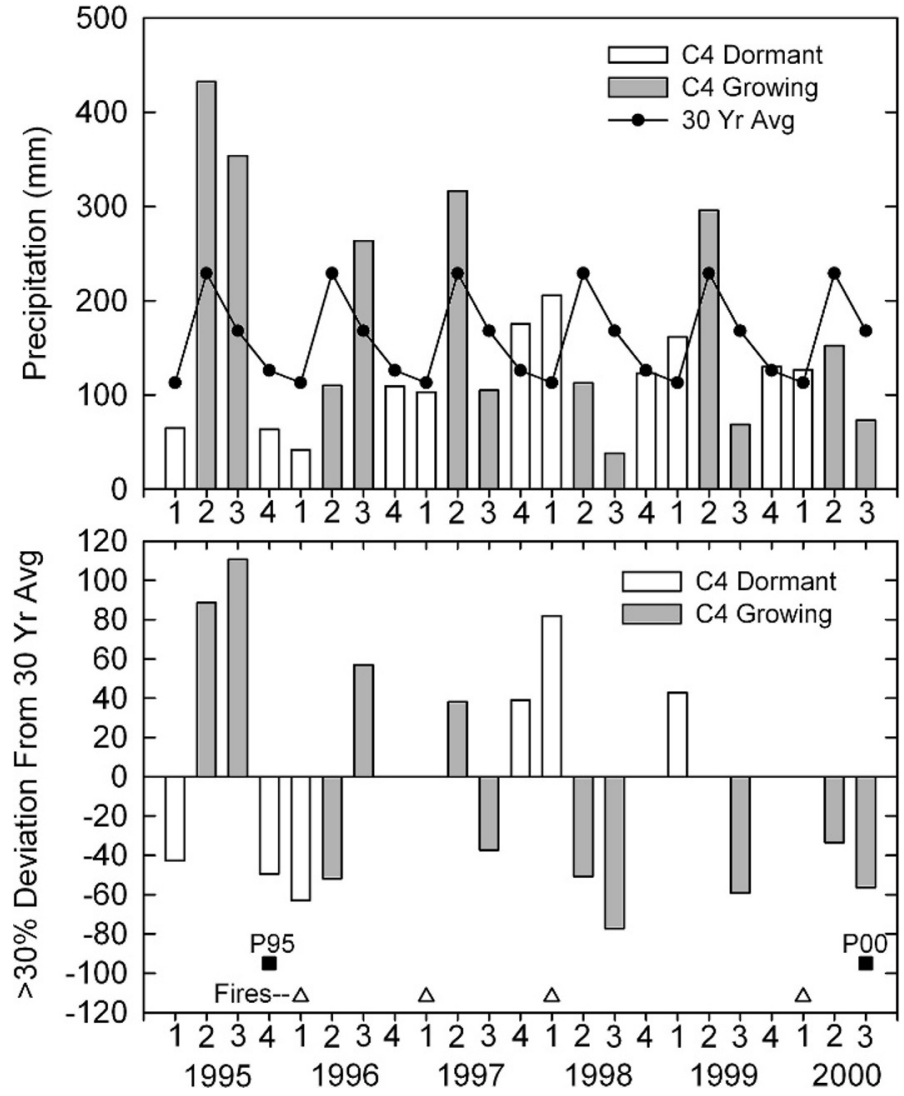

Figure 1. Precipitation at the research site in 3-mo quarterly periods (bars), 1995-2000, compared to the 30-yr average (line; top), and quarterly periods when precipitation deviated by $>30 \%$ (+ or - ) from normal (bottom). Any deviation $<30 \%$ of normal was not shown. Quarterly periods: 1 indicates January-March; 2, April-June; 3, JulySeptember; and 4, October-December. Open bars indicate periods 1 and $4, \mathrm{C}_{4}$ grasses dormant; gray bars, periods 2 and $3, \mathrm{C}_{4}$ grasses' growing season. Filled squares indicate aerial images; open triangles, when fires were applied.

achieve $3000-4000 \mathrm{~kg} \cdot \mathrm{ha}^{-1}$ herbaceous fine fuel, as would be expected under mesquite-free conditions and a strong $\mathrm{C}_{4}$ midgrass component, we elected to burn if 1500 $2000 \mathrm{~kg} \cdot \mathrm{ha}^{-1}$ was accumulated (Ansley et al. 1998; Ansley and Jacoby 1998). During drought years, one paddock rather than two paddocks were burned in the 8-paddock strategies and fire was not applied in the 4-paddock strategies; the deferred paddock was grazed instead. Paddocks were fenced in spring 1995 and first burns were conducted in January-March 1996.

\section{Fire and Herbicide Treatment History}

Precipitation was $100 \%$ above normal during the $1995 \mathrm{C}_{4}$ grass growing season (April-September) and yielded high herbaceous fine fuel loads for the first set of fires in 1996 (Fig. 1). However, extreme drought, defined here as any quarterly (3-mo) period with $>30 \%$ below the 30 -yr average, and high winds from October 1995-March 1996 limited the number of days that we could safely burn blacklines and apply headfires. As a result we were able to burn only five of the eight paddocks that were scheduled to be burned before spring green-up. One paddock in each $4: 3 \mathrm{~F}$ strategy replicate, one paddock in each 
Table 1. Planned burns vs. completed paddock burns on the Kite Camp study, 1996-2000.

\begin{tabular}{|c|c|c|c|}
\hline Burn dates & $\begin{array}{l}\text { Original schedule } \\
\text { of paddocks to } \\
\text { be burned }\end{array}$ & $\begin{array}{l}\text { Total } \\
\text { paddocks } \\
\text { burned }\end{array}$ & $\begin{array}{l}\text { Number of paddocks } \\
\text { burned in each replicate } \\
\text { of each strategy }{ }^{1}\end{array}$ \\
\hline January-March 1996 & 8 & 5 & $\begin{array}{l}\text { 8:1F ( } 1 \text { paddock in each of } \\
2 \text { replicates) } \\
\text { 4:1F ( } 1 \text { paddock in replicate } \\
\text { no. } 1 \text { ) } \\
\text { 4:1F/ } \mathrm{H} \text { ( } 1 \text { paddock in each } \\
\text { of } 2 \text { replicates) }\end{array}$ \\
\hline January-March 1997 & 8 & 1 & $\begin{array}{l}\text { 4:1F (1 paddock in replicate } \\
\text { no. 2) }\end{array}$ \\
\hline January-March 1998 & 8 & 6 & $\begin{array}{l}\text { 8:1F ( } 2 \text { paddocks in each of } \\
2 \text { replicates) } \\
\text { 4:1F ( } 1 \text { paddock in each of } \\
2 \text { replicates) }\end{array}$ \\
\hline $\begin{array}{l}\text { January-March } \\
1999^{2}\end{array}$ & 6 & 0 & No fires conducted \\
\hline January-March 2000 & 6 & 2 & $\begin{array}{l}\text { 8:1F ( } 1 \text { paddock in each of } \\
2 \text { replicates) }\end{array}$ \\
\hline Total 1996-2000 & 36 & 14 & \\
\hline
\end{tabular}

18:1F indicates 8-paddock, 1-herd; 4:1F, 4-paddock, 1-herd; and 4:1F/H, 4-paddock, 1-herd, fire or herbicide.

${ }^{2}$ Planned burns were reduced from eight to six in 1999 because the method for mesquite control was changed in the 4-paddock, 1-herd with fire or herbicides $(4: 1 / \mathrm{F} / \mathrm{H})$ strategy.

8:1F strategy replicate, and one paddock in one of the $4: 1 \mathrm{~F}$ strategy replicates were burned in winter to early-spring 1996 (Table 1). The 1996 fires were moderate- to high-intensity due to high fine fuel loads and dry conditions (Table 2).

Extreme drought in the first two quarters of 1996 limited fine fuel accumulation prior to winter 1997, in spite of abovenormal, late-growing-season precipitation (Fig. 1). Therefore, we decided to burn only one paddock in winter 1997 in the
4:1F strategy replicate that was not burned in 1996 . Thus, by spring 1997, all strategy replicates had at least one paddock burned (Table 1). After above-normal precipitation in AprilJune 1997, fine fuel was sufficient to burn two paddocks in each 8:1F strategy and one paddock in each 4:1F strategy (but none in the $4: 3 \mathrm{~F}$ strategies) in winter 1998 . However, with the exception of one fire (paddock SR5), the 1998 fires were of low to moderate intensity due to well-above-normal winter precipitation, which increased $\mathrm{C}_{3}$ grass growth and fine fuel green tissue content (Fig. 1; Table 2).

A severe drought from April-September 1998 prevented burning in 1999 due to low fine fuel. Above-average precipitation in the first half of 1999 increased fine-fuel accumulation but it remained below desired levels. Therefore, burning in 2000 was limited to one paddock in each of the $8: 1 \mathrm{~F}$ strategies (Table 1). Low fine fuel limited intensity of the 2000 fires (Table 2).

Severe droughts in 1996 and 1998 (Fig. 1) forced discontinuation of the 4:3F strategies due to lack of forage and an inability to accumulate sufficient fine fuel for fire. Therefore, in 1998, these replicate strategies were converted to 4:1 rotational strategies with aerial application of herbicide as the method of mesquite control. These strategies had a prescribed fire in one paddock in 1996 and herbicide aerial spray $\left(0.28 \mathrm{~kg} \cdot \mathrm{ha}^{-1}\right.$ clopyralid $+0.28 \mathrm{~kg} \cdot \mathrm{ha}^{-1}$ triclopyr; see Ansley et al. 2003) in the other paddocks in late June 1999. This strategy was designated as " $4: 1$ fire-or-herbicide" (4:1F/H). Herbicide spraying was conducted by commercial fixedwing aircraft between 0700-1000 hours (air temperature 21$32^{\circ} \mathrm{C}$; wind speed $2-5 \mathrm{~m} \cdot \mathrm{s}^{-1}$ ) and was concentrated on the clay loam soils where mesquite cover was greatest. Soil temperature at $46 \mathrm{~cm}$ depth was $>24^{\circ} \mathrm{C}$.

\section{Weather, Fuel, and Fire Behavior}

Weather variables, air temperature, relative humidity (RH), and wind speed (4-m height) were measured immediately prior

Table 2. Weather and fine fuel conditions for each paddock fire, visual estimate of fire intensity (H indicates high; M, moderate; L, low) and mesquite top-kill, 1996-2000. Data are shown in chronological order by burn date. Paddocks are identified (ID) according to their sequential time of treatment in each strategy (P1, P2...etc.) and with their actual name (GH1, GC4...etc.). rep. indicates replicate(s); seq., sequential; AT, air temperature; WS, wind speed; FF, herbaceous fine fuel; and est., estimate.

\begin{tabular}{|c|c|c|c|c|c|c|c|c|}
\hline Burn dates & $\begin{array}{c}\text { Strategy, rep., and seq. } \\
\text { paddock ID for each strategy }{ }^{1}\end{array}$ & $\begin{array}{c}\text { Actual } \\
\text { paddock ID }\end{array}$ & $\begin{array}{l}\text { AT } \\
\left({ }^{\circ} \mathrm{C}\right)\end{array}$ & $\begin{array}{l}\mathrm{RH} \\
(\%)\end{array}$ & $\begin{array}{c}\text { WS } \\
\left(m \cdot \mathrm{s}^{-1}\right)\end{array}$ & $\begin{array}{c}\mathrm{FF} \\
\left(\mathrm{kg} \cdot \mathrm{ha}^{-1}\right)\end{array}$ & $\begin{array}{l}\text { Visual est. of fire } \\
\text { intensity }^{2}\end{array}$ & $\begin{array}{l}\text { Mesquite } \\
\text { top-kill (\%) }\end{array}$ \\
\hline 16 January 1996 & 4:3F, Rep 1, P1 & $\mathrm{GH} 1$ & 23.9 & 19 & 3.34 & 2790 & $\mathrm{H}$ & 93 \\
\hline 24 January 1996 & 4:3F, Rep 2, P1 & GC4 & 14.4 & 24 & 2.67 & 3522 & $\mathrm{H}$ & 91 \\
\hline 07 February 1996 & 8:1F, Rep 1, P1 & SR7 & 26.7 & 30 & 5.12 & 1906 & M & 57 \\
\hline 21 February 1996 & 4:1F, Rep 1, P1 & TP2 & 25.6 & 19 & 1.78 & 3507 & $\mathrm{H}$ & 98 \\
\hline 01 April 1996 & 8:1F, Rep 2, P1 & LC2 & 21.1 & 14 & 2.67 & 3026 & $\mathrm{H}$ & 97 \\
\hline 07 March 1997 & 4:1F, Rep 2, P1 & $\mathrm{BC} 2$ & 20.0 & 38 & 5.78 & 1792 & M & 34 \\
\hline 27 January 1998 & $8: 1 F, \operatorname{Rep} 1, \mathrm{P} 2$ & SR5 & 21.1 & 20 & 4.67 & 2723 & $\mathrm{H}$ & 77 \\
\hline 27 January 1998 & 8:1F, Rep 2, P2 & LC4 & 21.7 & 21 & 5.34 & 1861 & M & 43 \\
\hline 11 February 1998 & 4:1F, Rep 1, P2 & TP1 & 17.2 & 30 & 3.34 & 1619 & $\mathrm{~L}$ & 15 \\
\hline 24 February 1998 & 8:1F, Rep 2, P3 & LC5 & 23.3 & 40 & 2.67 & 1190 & L & 19 \\
\hline 25 February 1998 & 4:1F, Rep 2, P2 & $\mathrm{BC} 3$ & 22.8 & 29 & 6.23 & 1373 & M & 40 \\
\hline 25 February 1998 & 8:1F, Rep 1, P3 & SR6 & 22.2 & 22 & 7.12 & 2099 & M & 51 \\
\hline 19 January 2000 & 8:1F, Rep 1, P4 & SR1 & 21.1 & 37 & 4.67 & 1057 & $\mathrm{~L}$ & 23 \\
\hline 08 February 2000 & 8:1F, Rep 2, P4 & LC8 & 23.9 & 22 & 3.56 & 1172 & $M$ & 44 \\
\hline
\end{tabular}

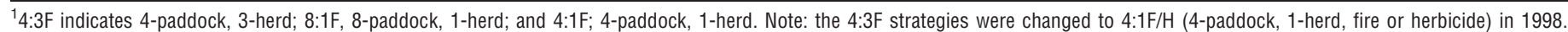
${ }^{2}$ Fire intensity: high $(\mathrm{H})$ indicates flame heights $>3 \mathrm{~m}$; moderate $(\mathrm{M})$, flame heights $1-3 \mathrm{~m}$; and low $(\mathrm{L})$, flame heights $<1 \mathrm{~m}$. 
to each paddock fire. Herbaceous fine fuel was determined by clipping 20-40 $0.25-\mathrm{m}^{2}$ frames randomly located within interstitial spaces between mesquite on dominant soil types in each paddock a few weeks prior to burning. Samples were clipped, oven-dried, and weighed. Fires were given a general rating of high ( $>3 \mathrm{~m}$ flame height), moderate (1-3 m), or low $(<1 \mathrm{~m})$ based on photographs, videotape, and visual assessment at multiple sites within each paddock.

\section{Mesquite Top-Kill Evaluations}

Mesquite top-kill (defined here as the percent of trees in a stand with $100 \%$ aboveground mortality) by each paddock fire was measured at $10-\mathrm{m}$ intervals along three sets of three parallel lines, each $200 \mathrm{~m}$ long, randomly located within the dominant soil types in each paddock during the fall, $\sim 8$ mo following each winter fire. The nearest trees at each point (usually 1-5 but no more than 8 trees) were evaluated and placed into one of four categories: 1) stem foliage only with no basal sprouts, 2) stem foliage plus basal sprouts, 3) basal sprouts only, and 4) apparent whole plant mortality (root-kill). Total number of trees evaluated along each line ranged from 80 to 120 , depending on stand density. The number of trees counted in the last two categories (basal sprouts only and root-kill) were combined and divided by the total number of trees evaluated to determine percent of trees with complete top-kill. The same procedure was used to evaluate the herbicide treatments, although evaluations were conducted $\sim 15$ mo after the summer sprays.

\section{Mesquite Landscape Cover Quantification}

Remote sensing of strategy-level changes in mesquite canopy cover was used to estimate the effectiveness of each strategy on mesquite suppression. Color infrared (CIR) aerial images of all strategies (1:7 000) were taken in October 1995 and September 2000. Images were scanned and geo-referenced in ArcView Geographic Information System using ortho-quads available from the US Geological Survey (Ansley et al. 2001). Green vegetation appears as varying shades of pink or red on CIR images. Normally, on late summer/early fall images, mesquite canopies appear as a bright pink color and the dormant herbaceous understory is light gray. However, because of wellabove-average precipitation, herbaceous vegetation remained green throughout 1995 and it was not possible to use the automated color classification system within ArcView to digitally separate mesquite cover from understory vegetation because both vegetation types had similar shades of pink. We could visually discern individual mesquite canopies from the herbaceous layer because canopy margins cast a small shadow. Therefore, mesquite cover was quantified on the images using a variation of the line intercept technique by Canfield (1941). Two 1 -ha $(100 \times 100 \mathrm{~m})$ plots each were randomly located on clay loam and shallow soil types on images of each paddock of each strategy. Ten parallel computer-generated lines, each scaled at 100-m length, were placed in each 1-ha plot and mesquite canopy intercept was measured manually along each line using the distance measure feature in ArcView (after Ansley et al. 2003). Cover values from images were verified with field transects $\left(R^{2}=0.94 ; y=0.97 \times-0.98 ; n=12\right)$. The same process was used for images taken in 2000 , although color
Table 3. Total area within paddocks and strategies at Kite Camp and paddock area relative to strategy area. All values are followed by SE in parentheses $(n=2)$.

\begin{tabular}{|c|c|c|c|c|c|}
\hline $\begin{array}{c}\text { Strategy } \\
I^{1}{ }^{1}\end{array}$ & $\begin{array}{c}\text { Total } \\
\text { strategy } \\
\text { area (ha) }\end{array}$ & $\begin{array}{c}\text { Sequential } \\
\text { paddock ID }\end{array}$ & $\begin{array}{l}\text { Paddock } \\
\text { treatment }\end{array}$ & $\begin{array}{l}\text { Paddock } \\
\text { area (ha) }\end{array}$ & $\begin{array}{l}\text { Paddock area } \\
\text { relative to } \\
\text { strategy area }\end{array}$ \\
\hline CU & $1416(88)$ & P1 & None & $1416(88)$ & $1.0(0)$ \\
\hline \multirow[t]{4}{*}{$4: 1 F$} & $1980(21)$ & P1 & Fire 1996 & $501(5)$ & $0.25(0.001)$ \\
\hline & & P2 & Fire 1998 & $499(42)$ & $0.25(0.02)$ \\
\hline & & P3 & None & $428(26)$ & $0.22(0.01)$ \\
\hline & & P4 & None & $551(52)$ & $0.28(0.03)$ \\
\hline \multirow[t]{4}{*}{$4: 1 F / H$} & $1320(43)$ & P1 & Fire 1996 & $305(20)$ & $0.23(0.01)$ \\
\hline & & P2 & $\begin{array}{c}\text { Herbicides } \\
1999\end{array}$ & $378(74)$ & $0.28(0.05)$ \\
\hline & & P3 & $\begin{array}{c}\text { Herbicides } \\
1999\end{array}$ & $337(80)$ & $0.26(0.07)$ \\
\hline & & P4 & $\begin{array}{c}\text { Herbicides } \\
1999\end{array}$ & 301 (28) & $0.23(0.01)$ \\
\hline \multirow[t]{8}{*}{$8: 1 F$} & 2025 (137) & P1 & Fire 1996 & $218(18)$ & $0.11(0.02)$ \\
\hline & & P2 & Fire 1998 & $249(46)$ & $0.12(0.01)$ \\
\hline & & P3 & Fire 1998 & $256(33)$ & $0.13(0.01)$ \\
\hline & & P4 & Fire 2000 & $188(23)$ & $0.09(0.01)$ \\
\hline & & P5 & None & $278(60)$ & $0.14(0.04)$ \\
\hline & & P6 & None & $248(11)$ & $0.12(0.01)$ \\
\hline & & P7 & None & $283(62)$ & $0.14(0.02)$ \\
\hline & & P8 & None & $305(62)$ & $0.15(0.02)$ \\
\hline
\end{tabular}

${ }^{1} \mathrm{ID}$ indicates identification; $\mathrm{CU}$, continuously grazed control, mesquite untreated; 4:1F, 4paddock, 1-herd, fire; 4:1F/H, 4-paddock, 1-herd, fire or herbicide; and 8:1F, 8-paddock, 1herd, fire.

separation between mesquite canopies and understory was clear because of late-summer herbaceous senescence. Cover was determined on 1360 separate 100-m transect lines (34 paddocks $\times 2$ soil types per paddock $\times 21$-ha plots per soil type $\times 10$ lines per plot); far more than would be possible using conventional field measurements.

\section{Scaling Mesquite Cover Changes}

The percent change in mesquite cover in each soil type was scaled to the paddock and strategy levels for each strategy $(4: 1$, $8: 1$, etc.). The factor for scaling to the paddock level was percent area of each soil type (clay loam or shallow clay) in each paddock. Factors for scaling to the strategy level were percent area of each soil type in each paddock and percent area of each paddock relative to the total area of each strategy. Riparian areas (loamy bottomland soils) were excluded from the analysis.

Mean land area within each strategy ranged from 1320 to 2025 ha with little variation in size within each strategy (Table 3). Area of paddocks within each strategy was not exactly the same but was roughly $25 \%$ of the total area in $4-$ paddock strategies and $12.5 \%$ of the total area in 8-paddock strategies. The percentage of total land area that was clay loam soil ranged from $28 \%$ to $64 \%$ at the paddock level and $34 \%$ to $52 \%$ at the strategy level (Table 4). The percentage of total land area that was shallow clay soil ranged from $20 \%$ to $59 \%$ at the paddock level and $39 \%$ to $53 \%$ at the strategy level. Comparing all four strategies, the CU strategy had slightly more shallow clay soils than did the other strategies. Loamy 
Table 4. Percent of total area of soil types within paddocks and strategies at Kite Camp. All paddock and strategy mean values are followed by SE in parentheses $(n=2)$.

\begin{tabular}{|c|c|c|c|c|c|c|c|}
\hline \multirow[b]{2}{*}{ Strategy ID ${ }^{1}$} & \multirow[b]{2}{*}{ Sequential paddock ID } & \multirow[b]{2}{*}{ Paddock treatment } & \multicolumn{2}{|c|}{ Paddock } & \multicolumn{3}{|c|}{ Strategy } \\
\hline & & & Clay loam \% & Shallow clays \% & Clay loam \% & Shallow clays \% & Loamy bottom \% \\
\hline CU & P1 & None & $33.7(9.7)$ & $53.1(10.0)$ & $33.7(9.7)$ & $53.1(10.0)$ & $13.2(0.3)$ \\
\hline \multirow[t]{4}{*}{$4: 1 F$} & P1 & Fire 1996 & $33.4(5.3)$ & $59.4(5.5)$ & $46.3(13.7)$ & $40.3(15.2)$ & $13.4(1.5)$ \\
\hline & P2 & Fire 1998 & $59.0(14.2)$ & $28.1(14.8)$ & & & \\
\hline & P3 & None & $39.4(29.7)$ & $43.7(34.7)$ & & & \\
\hline & P4 & None & $53.4(5.6)$ & $29.9(5.9)$ & & & \\
\hline \multirow[t]{4}{*}{$4: 1 F / H$} & P1 & Fire 1996 & $64.2(17.6)$ & $20.0(10.4)$ & $51.8(16.4)$ & $38.7(10.3)$ & $9.5(6.1)$ \\
\hline & P2 & Herbicides 1999 & $39.9(5.1)$ & $45.2(16.0)$ & & & \\
\hline & P3 & Herbicides 1999 & $51.3(32.2)$ & $42.1(26.8)$ & & & \\
\hline & P4 & Herbicides 1999 & $51.7(21.0)$ & $47.4(20.1)$ & & & \\
\hline \multirow[t]{7}{*}{$8: 1 F$} & P1 & Fire 1996 & $28.7(19.9)$ & $49.3(20.8)$ & $44.3(6.1)$ & $43.4(5.9)$ & $12.3(0.2)$ \\
\hline & P2 & Fire 1998 & $63.4(2.8)$ & $36.6(2.8)$ & & & \\
\hline & P3 & Fire 1998 & $48.8(14.8)$ & $51.2(14.8)$ & & & \\
\hline & P4 & Fire 2000 & $39.6(8.1)$ & $25.8(8.0)$ & & & \\
\hline & P5 & None & $44.0(26.0)$ & $39.7(33.6)$ & & & \\
\hline & P6 & None & $55.2(16.4)$ & $42.1(13.6)$ & & & \\
\hline & P7 & None & $46.2(22.2)$ & $53.5(22.5)$ & & & \\
\hline
\end{tabular}

${ }^{1} \mathrm{ID}$ indicates identification; CU, continuously grazed control, mesquite untreated; 4:1F, 4-paddock, 1-herd, fire; 4:1F/H, 4-paddock, 1-herd, fire or herbicide; and 8:1F, 8-paddock, 1-herd, fire.

bottomland soils ranged from $10 \%$ to $13 \%$ of the total area among all strategies.

\section{Statistical Analysis}

Individual regressions were performed between mesquite topkill by fire (dependent variable) and independent variables herbaceous fine fuel, $\mathrm{RH}$, air temperature, and wind speed for the 14 burned paddocks. A multiple regression determined the relative influence of these weather and fuel variables on mesquite top-kill by fire using the model

$$
\mathrm{TK}=\beta_{0}+\left(\beta_{1}\right)(\mathrm{FF})+\left(\beta_{2}\right)(\mathrm{RH})+\left(\beta_{3}\right)(\mathrm{AT})+\left(\beta_{4}\right)(\mathrm{WS})
$$

where TK is mesquite percent top-kill; $\beta_{0 \ldots 4}$ are coefficients, FF is herbaceous fine fuel $\left(\mathrm{kg} \cdot \mathrm{ha}^{-1}\right), \mathrm{RH}$ is relative humidity (\%); AT is air temperature $\left({ }^{\circ} \mathrm{C}\right)$, and WS is wind speed $\left(\mathrm{m} \cdot \mathrm{s}^{-1}\right)$. PROC GLM in SAS was used to determine Type I (sequential contribution of coefficients) and Type III (contribution of each coefficient apart from all other coefficients) $P$ values for the independent variables (Freund and Littell 1981; SAS 2002). Order of variables in the model was determined by highest to lowest correlation in the individual regressions. Tolerance and variance inflation tests (VIF) were performed in PROC REG to determine multicollinearity (Freund and Littell 1986). The Mallow's C(p) statistic in PROC REG (Draper and Smith 1981; Freund and Littell 1986; SAS 2002) was used to determine the optimum combination of independent variables. Significance was set at $P<0.10$.

To assess changes in mesquite cover over time, subsamples of mesquite percent cover in each paddock were pooled to yield a single value per soil type and year. Paddock cover values for each soil type and year were then averaged within each strategy to yield a strategy replicate value. Mesquite cover was analyzed within each soil type using a repeated measures analysis where main effects were strategy $(4: 1 \mathrm{~F}, 8: 1 \mathrm{~F}, 4: 1 \mathrm{~F} / \mathrm{H}$, and $\mathrm{CU})$ and year (1995, 2000), with two replicates per strategy. Strategy main effect was tested using the strategy by year error term $(\mathrm{df}=3$; SAS 2002). Year main effect was tested using the pooled error term $(\mathrm{df}=8)$. Mesquite cover values for each paddock in each strategy are also reported with standard error values $(n=2)$.

The percent change in mesquite cover from 1995 (pretreatment) to 2000 that was scaled to either the paddock or whole strategy level was analyzed using a completely randomized design with paddock within strategy $(4: 1 \mathrm{~F}, 8: 1 \mathrm{~F}, 4: 1 \mathrm{~F} / \mathrm{H}$, and $\mathrm{CU})$ as the main effect $(n=2)$. Analysis of changes in mesquite cover per paddock was only performed in the $4: 1$ or $8: 1$ strategies. Percentage data were Arcsine transformed prior to analysis. Means were separated using a protected LSD $(P \leq 0.10)$. All standard error values reported in the Tables and Figures were based on an $n=2$ replicates per strategy.

\section{RESULTS}

\section{Fire History and Intensity}

The experimental period was characterized by precipitation extremes. Seventeen of the 23 quarterly (3-mo) periods from January 1995 to September 2000 had precipitation that was $>30 \%$ above or below the 30 -yr average (Fig. 1). After the 1996 fires, seven of the 10 quarterly periods from 1996 to 2000 that were defined as growing periods for $\mathrm{C}_{4}$ grasses (i.e., AprilJune; July-September) had extreme drought $(>30 \%$ below normal precipitation). This greatly limited fine fuel accumulation and the number of paddocks we could burn. During the 5yr period from 1996-2000, two of four paddocks in each of the two 4:1F replicate strategies, four of eight paddocks in each of the two 8:1F replicate strategies, and one paddock in each of the two 4:3F replicate strategies were burned. This total of 14 burned paddocks was less than half of the original 36 paddocks scheduled to be burned (Table 1). 

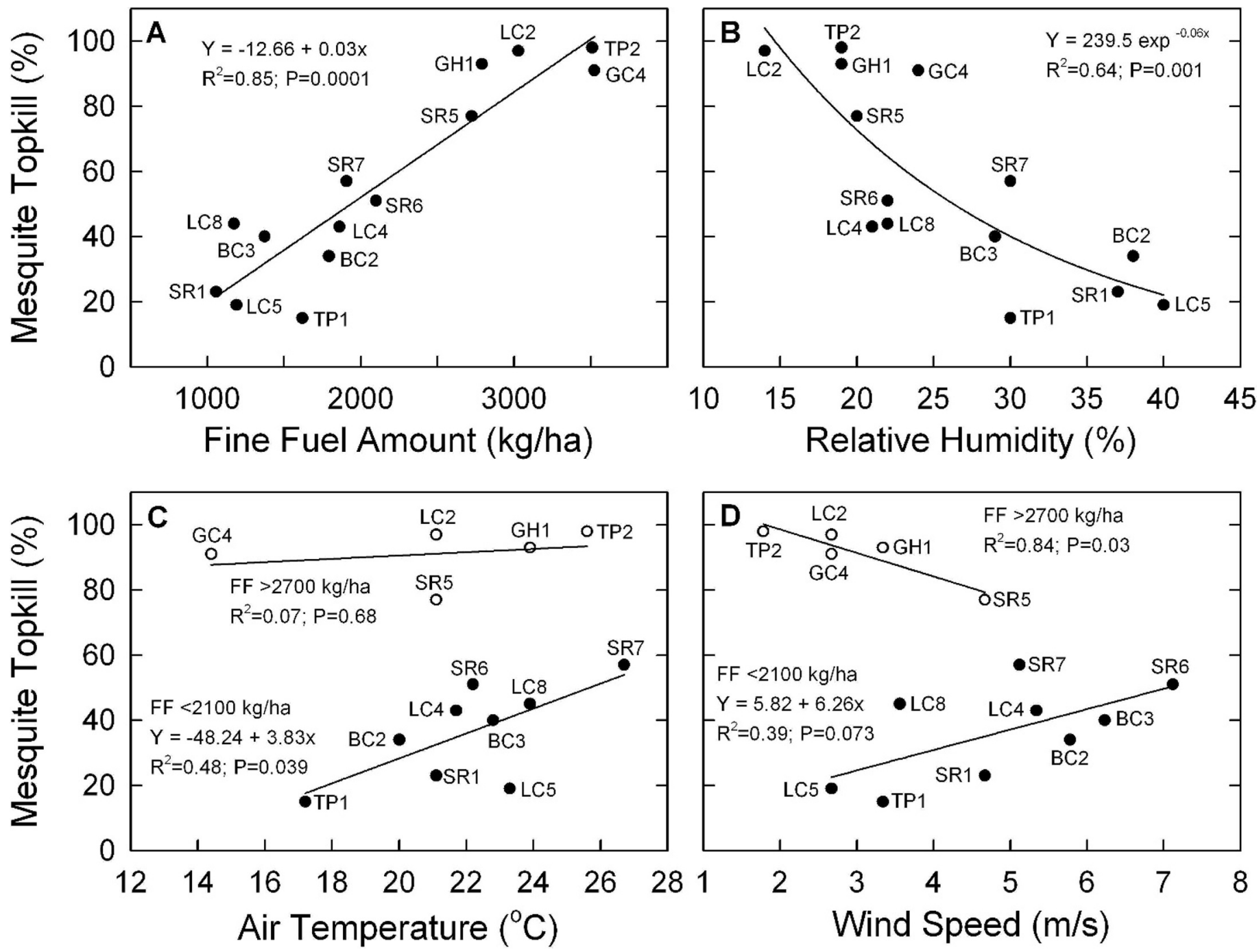

Figure 2. Relationship between mesquite top-kill and A, herbaceous fine fuel, B, relative humidity, C, air temperature, D, wind speed of 14 paddocks burned between 1996 and 2000. Each point represents a single paddock and is labeled with a paddock identification. In panels $\mathrm{C}$ and D, the data sets are divided into paddocks with $>2700 \mathrm{~kg} \cdot \mathrm{ha}^{-1}$ (open circles) and $<2100 \mathrm{~kg} \cdot \mathrm{ha}^{-1}$ (filled circles) and have separate regressions. Data are from Table 2.

In addition to growing season droughts that limited fine fuel accumulation, dormant season (October-March) precipitation was above normal or near normal in every dormant season quarterly period from 1996 to 2000 (Fig. 1). This increased $C_{3}$ grass growth, which limited fire intensity. Thus, of the 14 fires conducted, five had high $(>60 \%)$, six had moderate (30$60 \%)$, and three had low $(<30 \%)$ mesquite top-kill (Table 2$)$. Mesquite root-kill was $<2 \%$ in all fires.

\section{Fine Fuel and Weather Effects on Mesquite Top-Kill by Fire}

Regressions between each independent variable and mesquite top-kill revealed a significant $\left(P \leq 0.0001 ; R^{2}=0.85\right)$ positive linear relationship between fine fuel amount and mesquite topkill by fire (Fig. 2A). In addition, there was a significant $\left(P \leq 0.0006 ; R^{2}=0.64\right)$ negative exponential relationship between RH and top-kill (Fig. 2B). There was no relationship between air temperature (AT) and top-kill or between wind speed (WS) and top-kill when all 14 paddocks were included.
However, when paddocks with fine fuel $>2700 \mathrm{~kg} \cdot \mathrm{ha}^{-1}$ were omitted and regressions were limited to the remaining nine paddocks that had $<2100 \mathrm{~kg} \cdot \mathrm{ha}^{-1}$, there was a significant $\left(P \leq 0.039 ; R^{2}=0.48\right)$ positive linear relationship between AT and top-kill (Fig. 2C).

Multiple regression utilizing four independent variables (Eq. 1) and data from all 14 paddock fires indicated a significant $\left(P \leq 0.0001 ; R^{2}=0.93\right)$ overall model:

$$
\begin{aligned}
\mathrm{TK}= & -19.87+(0.027)(\mathrm{FF})-(0.85)(\mathrm{RH}) \\
& +(1.88)(\mathrm{AT})-(0.46)(\mathrm{WS})
\end{aligned}
$$

Type I (sequential) $P$ values of independent variables indicated that greatest significance for mesquite top-kill resulted from FF $(P \leq 0.0001), \mathrm{RH}(P \leq 0.0327)$, and AT $(P \leq 0.0591)$. Type III (nonsequential) $P$ values of independent variables revealed that mesquite top-kill was associated with FF $(P \leq 0.0003)$ and AT $(P \leq 0.0598)$. Tolerance and VIF tests indicated no evidence of 

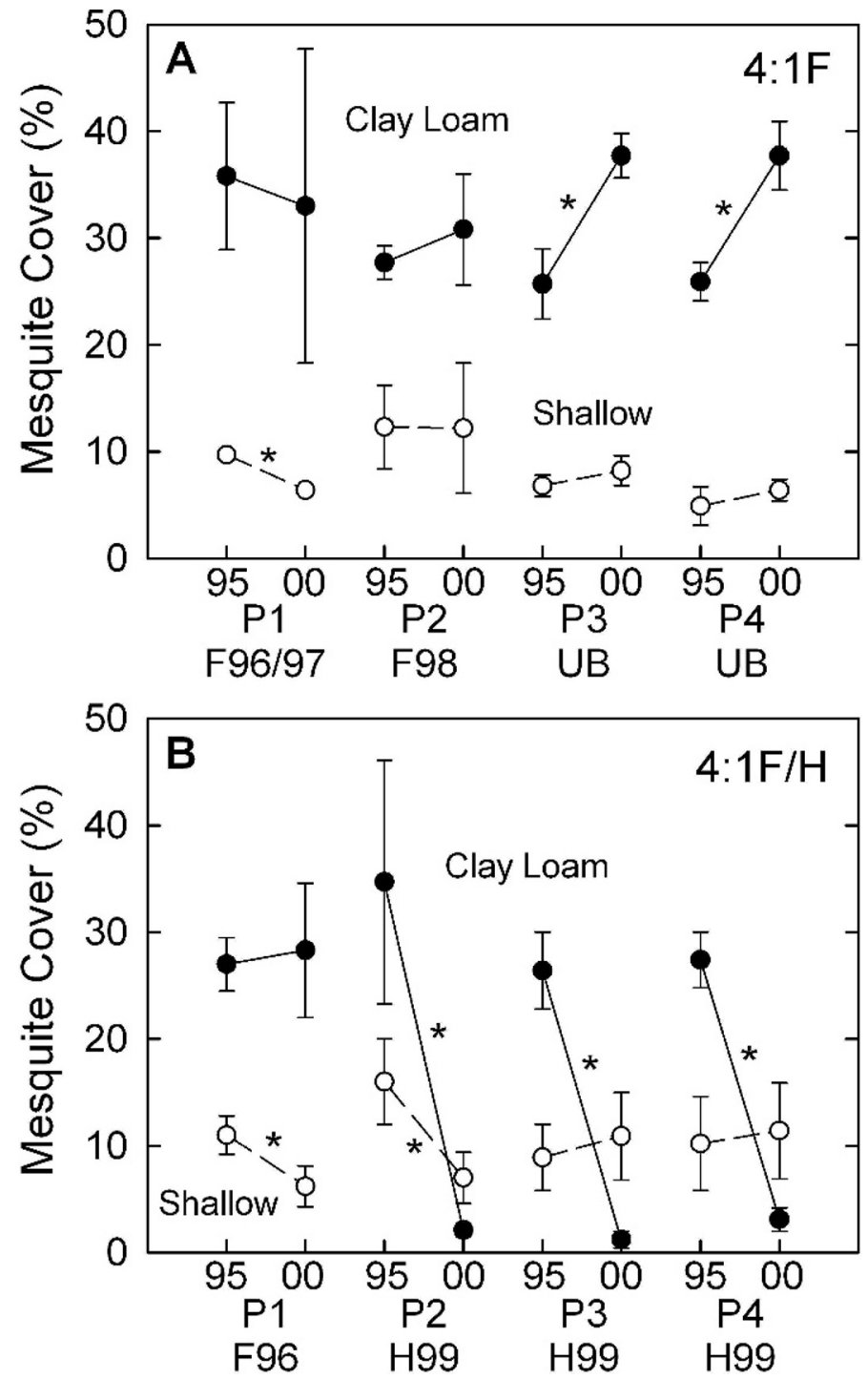

Figure 3. Mesquite cover from 1995 to 2000 within each paddock (P) and soil type (solid symbol indicates clay loam; open, shallow clays) and the mean of all four paddocks in the $\mathbf{A}, 4: 1 \mathrm{~F}$, and $\mathbf{B}, 4: 1 \mathrm{~F} / \mathrm{H}$ strategies ( $n=2$ for each paddock; vertical lines are $\pm 1 \mathrm{SE}$; asterisk indicates significant $[P \leq 0.05]$ change from 1995 to 2000). F indicates fire; $\mathrm{H}$, herbicide; and UB, unburned.

multicollinearity. Tolerance was $>0.10$ (range $0.41-0.89$ ) and VIF was $<10$ (range 1.12-2.45) for all independent variables. Mallow's $\mathrm{C}(\mathrm{p})$ best-fit statistic revealed that the highest ranked model included the three variables FF, RH, and AT $[C(p)=3.06]$. Multiple regression utilizing these three variables yielded the following model $\left(P \leq 0.0001 ; R^{2}=0.93\right)$ :

$$
\mathrm{TK}=-23.34+(0.028)(\mathrm{FF})-(0.84)(\mathrm{RH})+(1.89)(\mathrm{AT})
$$

Thus, the removal of wind speed made little difference to the model.

\section{Mesquite Cover Changes Per Soil Type and Strategy}

In the 4:1F strategy, one replicate of $\mathrm{P} 1$ paddocks was burned in 1996 and the other was burned in 1997. Mesquite top-kill from the 1996 fire was $98 \%$, but the 1997 fire yielded only

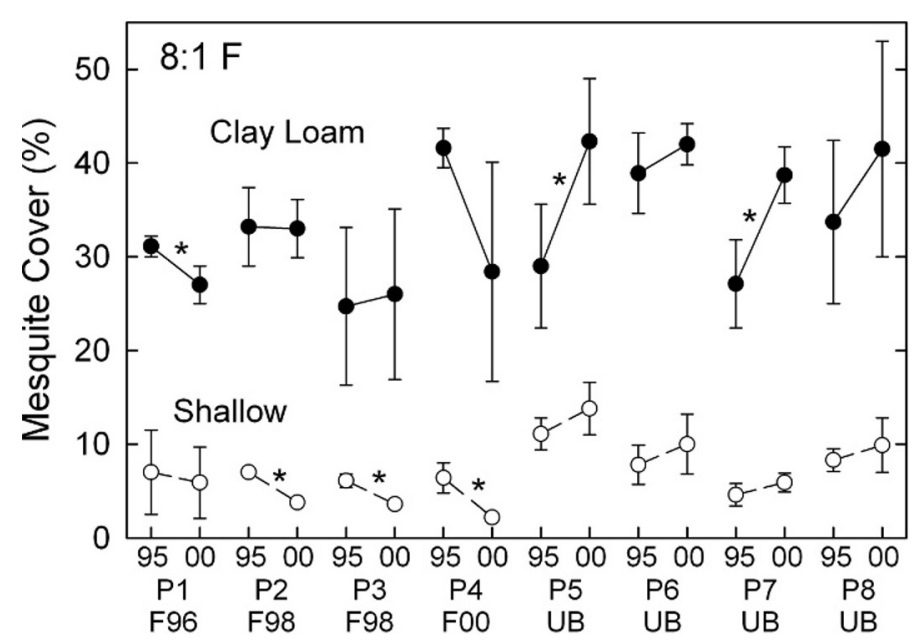

Figure 4. Mesquite cover from 1995 to 2000 within each paddock (P) and soil type (solid symbol indicates clay loam; open, shallow clays) and the mean of all eight paddocks in the $8: 1 \mathrm{~F}$ strategy $(n=2$ for each paddock; vertical lines are $\pm 1 \mathrm{SE}$; asterisk indicates significant $[P \leq 0.05]$ change from 1995 to 2000). F indicates fire, UB, unburned.

34\% top-kill (Table 2). The P2 paddock replicates were both burned in 1998 and had low (15\%) and moderate (40\%) topkill. There was no difference in mesquite cover on clay loam soils in P1 or P2 paddocks between 1995 and 2000, indicating that the fires collectively did not cause a long-term reduction in mesquite cover (Fig. 3A). However, compared to the significant $(P \leq 0.05)$ increase in mesquite cover on the unburned P3 and P4 paddocks, these fires at least prevented mesquite cover from increasing. On shallow soils, the 1996-1997 fires in P1 paddocks reduced $(P \leq 0.05)$ mesquite cover from 1995 to 2000.

In the 4:1F/H (formerly 4:3F) strategy, the 1996 fires topkilled most mesquite in both P1 paddock replicates $(91 \%$ and $93 \%$; Table 2), but this did not result in a significant reduction in mesquite cover on clay loam soils from 1995 to 2000 due to the rapid rate of mesquite regrowth (Fig. 3B). In contrast, on shallow soils, the 1996 fires reduced $(P \leq 0.05)$ mesquite cover from 1995 to 2000. The P2-P4 paddocks in each replicate strategy were treated with herbicides in 1999 that reduced $(P \leq 0.05)$ mesquite cover on clay loam soils from $\sim 30 \%$ to $<5 \%$. Much of the mesquite that occurred on shallow soils in paddocks P2-P4 was intentionally not sprayed because of light mesquite cover. However, some mesquite on shallow soils in the P2 paddocks received spray and mesquite cover was reduced $(P \leq 0.05)$.

In the 8:1F strategy, the 1996 fires top-killed most mesquite in both P1 paddock replicates (55\% and 97\%; Table 2), and this reduced $(P \leq 0.05)$ mesquite cover on clay loam soils from 1995 to 2000 (Fig. 4). In contrast, the 1998 fires in P2 and P3 paddock replicates did not reduce mesquite cover on clay loam soils from 1995 to 2000. The 2000 fires of P4 paddock replicates yielded low $(23 \%)$ and moderate $(47 \%)$ mesquite top-kill (Table 2) and this did not significantly change mesquite cover on clay loam soils from 1995 to 2000 (Fig. 4). However, fires in 1998 and 2000 reduced $(P \leq 0.05)$ mesquite cover on shallow soils. Compared to the significant $(P \leq 0.05)$ increase in mesquite cover on some of the unburned paddocks, the fires 


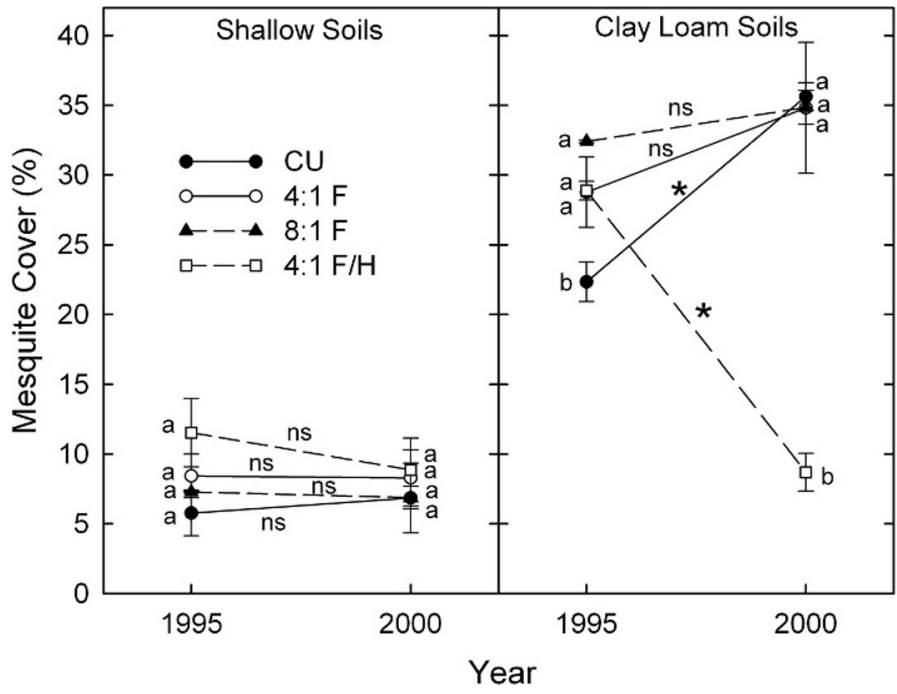

Figure 5. Mesquite cover from 1995 to 2000 in shallow clay soils and clay loam soils in each strategy when averaged over all paddocks in each strategy ( $n=2$; vertical lines are $\pm 1 \mathrm{SE}$ ). Means with the same letters within each soil type and year are not significantly different at $P \leq 0.05$. An asterisk indicates a significant $(P \leq 0.05)$ change from 1995 to 2000 within a strategy. $\mathrm{F}$ indicates fire; $\mathrm{H}$, herbicide; and ns, not significant.

at least prevented mesquite cover from increasing on clay loam soils.

Averaged over all paddocks in each strategy, mesquite cover on clay loam soils did not change $(P \leq 0.05)$ from 1995 to 2000 in the $4: 1 \mathrm{~F}$ or $8: 1 \mathrm{~F}$ strategies and was reduced $(P \leq 0.05)$ in the 4:1F/H strategy (Fig. 5). In contrast, mesquite cover increased $(P \leq 0.05)$ on clay loam soils in the CU strategy from $22.3 \%$ to $35.6 \%$. There was no change in mesquite cover on shallow soils in any of the strategies.

\section{Scaling Mesquite Changes Over Soil Types Within Paddocks}

Following scaling of mesquite cover changes over both soil types within paddocks, only the 1996-1997 fires (P1 paddocks) in the $4: 1 \mathrm{~F}$ strategy reduced $(P \leq 0.05)$ mesquite cover from 1995 to 2000 (Fig. 6A). Cover increased in the other three paddocks but at a slower $(P \leq 0.05)$ rate in the $\mathrm{P} 2$ paddocks than in the unburned P4 paddocks due to the 1998 fires.

In the 8:1F strategy, the P1-P4 paddock replicates that were burned all had a net negative change in mesquite cover from 1995 to 2000 when scaled over soil type (Fig. 6B). These responses were significantly $(P \leq 0.05)$ different from three of the unburned P5-P8 paddock replicates, which showed a gain in mesquite cover. In the $4: 1 \mathrm{~F} / \mathrm{H}$ strategy, mesquite cover decreased from 1995 to 2000 in all four paddocks due to the 1996 fire in P1 paddock replicates and the 1999 herbicidetreated in the P2-P4 paddock replicates (Fig. 6C). Among the herbicide-treated paddocks, percent reduction in mesquite cover was greatest $(P \leq 0.05)$ in the $\mathrm{P} 2$ paddock replicates because they had a greater initial cover of mesquite $(35 \%)$ than the P3 $(26 \%)$ or P4 (27\%) paddocks (Fig. 3B).

\section{Scaling Mesquite Cover Changes Over Soils and Paddocks}

Net change in mesquite cover, when scaled over soil type and land area of each paddock within each strategy, was $+34 \%$,

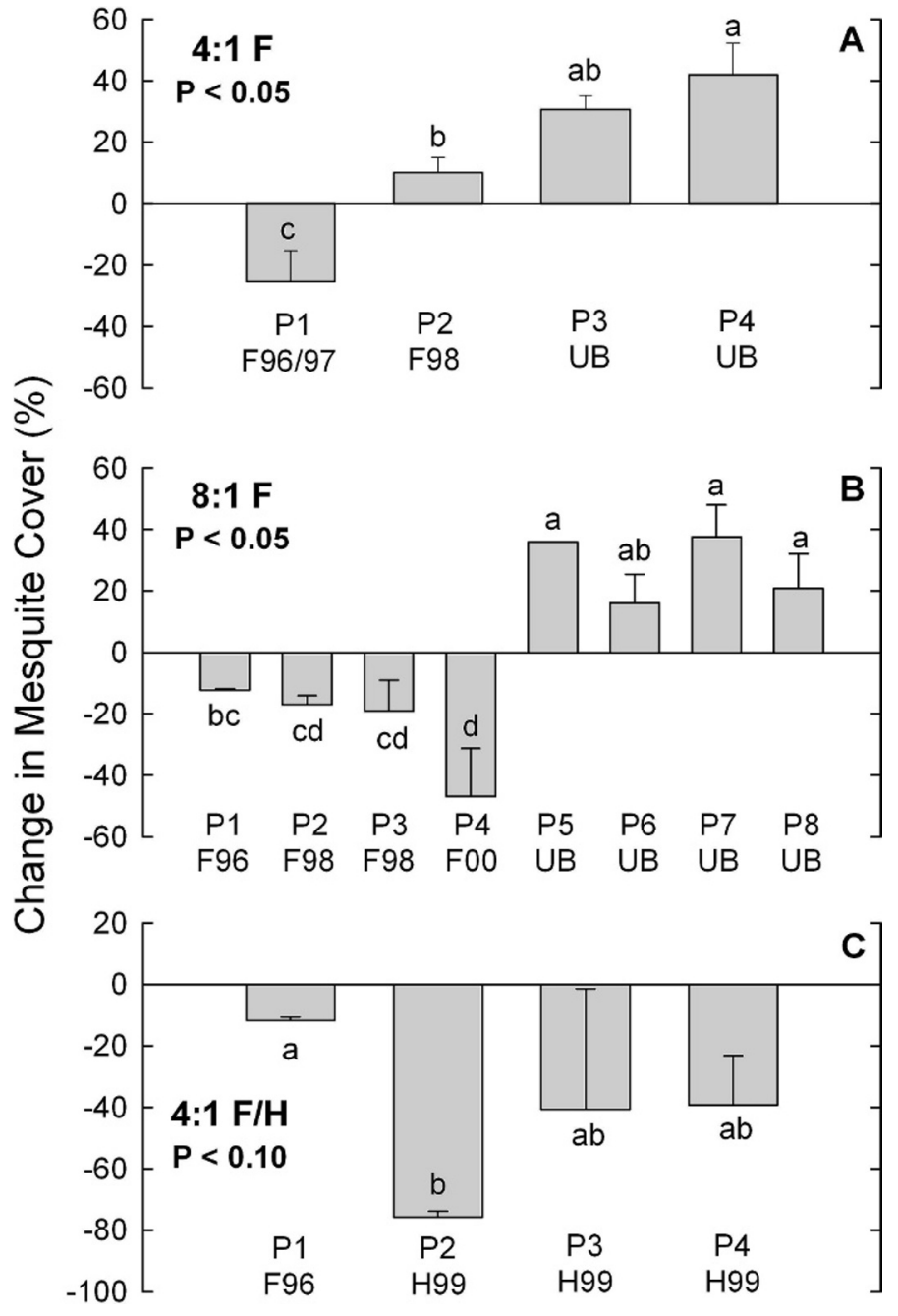

Figure 6. Percent change in mesquite cover from 1995 to 2000 within each paddock $(\mathrm{P})$ in $\mathbf{A}, 4: 1 \mathrm{~F}, \mathbf{B}, 8: 1 \mathrm{~F}$, and $\mathbf{C}, 4: 1 \mathrm{~F} / \mathrm{H}$ strategies when scaled over both soil types. Error bars indicate \pm 1 SE $(n=2)$. Means with the same letters are not significant at $P<0.05$.

$+15 \%,+5 \%$, and $-41 \%$ in the $\mathrm{CU}, 4: 1 \mathrm{~F}, 8: 1 \mathrm{~F}$, and $4: 1 \mathrm{~F} / \mathrm{H}$ strategies, respectively (Fig. 7). The only strategy that caused a significant $(P \leq 0.08)$ strategy-wide reduction in mesquite cover during the study period was the $4: 1 \mathrm{~F} / \mathrm{H}$ strategy. However, in the fire-only strategies, the strategy-level increase in mesquite cover was lower $(P \leq 0.08)$ in the 8:1F strategy compared to the CU strategy, with the $4: 1 \mathrm{~F}$ strategy intermediate.

\section{DISCUSSION}

In this study, five significant findings are presented. First, the rotational grazing and fire strategies $(4: 1 \mathrm{~F}$ and $8: 1 \mathrm{~F})$ slowed the increase in mesquite cover compared to the CU strategy but did not reduce it within the 5-yr time frame of the study. We quantified this difference in two ways. In a nonscaled assessment, mesquite cover, when averaged over all paddocks in each strategy, did not change from 1995 to 2000 in either the $4: 1$ or $8: 1$ strategies, yet it increased by $60 \%(22.3 \%$ to $35.6 \%)$ on clay loam soils in the CU strategy (Fig. 5). Secondly, when scaled over soil type and paddock area (Fig. 7), mesquite cover 


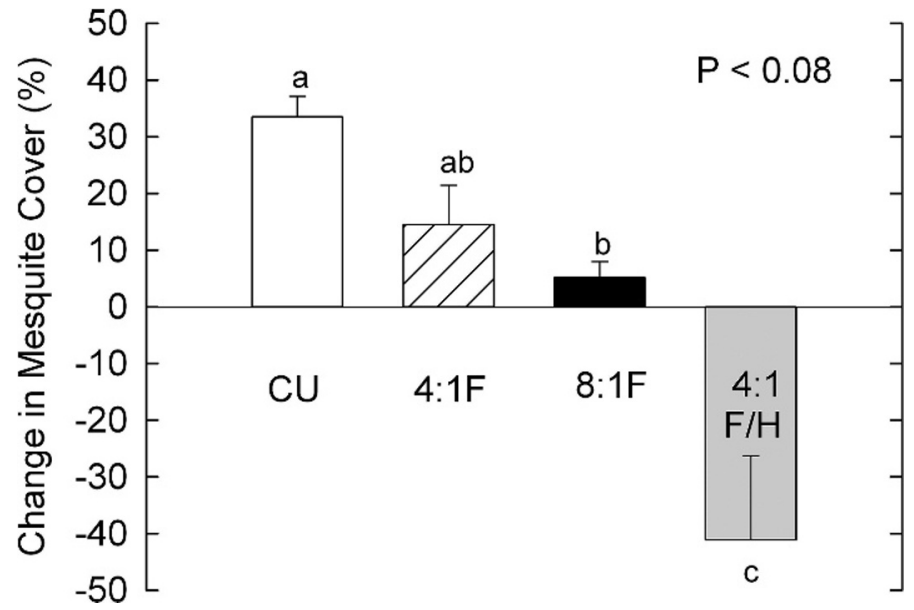

Figure 7. Percent change in mesquite cover from 1995 to 2000 within each management strategy when scaled over area per paddock in each strategy and area per soil type within each paddock. Error bars indicate \pm 1 $\mathrm{SE}(n=2)$. Means with similar letters are not significant at $P<0.05$. CU indicates continuously grazed control; 4:1F, 4-paddock, 1-herd, fire; 4:1F/ $\mathrm{H}$, 4-paddock, 1-herd, fire or herbicide; and 8:1F, 8-paddock, 1-herd, fire.

increased at a significantly $(P \leq 0.08)$ slower rate in the $8: 1 \mathrm{~F}$ strategy compared to the CU strategy, but there was no difference between the 4:1F strategy and the CU strategy. The scaled quantification thus isolated a difference in the performance of the $8: 1 \mathrm{~F}$ vs. the $4: 1 \mathrm{~F}$ strategies. Fire was easier to apply in the $8: 1 \mathrm{~F}$ than the $4: 1 \mathrm{~F}$ strategies during droughts because we could limit grazing deferral and burning to one paddock (i.e., $1 / 8$ or $12.5 \%$ of the area of each strategy) and rotate the herd on the remaining seven paddocks (or $87.5 \%$ of the area), whereas in the $4: 1 \mathrm{~F}$ strategies, we could not defer grazing in a paddock long enough to accumulate fuel for fire because the remaining three paddocks (or $75 \%$ of the area) could not sustain the herd for any length of time. Thus, eight paddocks provided more flexibility for burning in drought years than did the 4-paddock strategy.

The potential impacts of not treating mesquite can be profound because mesquite cover usually increases over time and herbaceous production on clay loam soils declines severely once mesquite achieves $>25 \%$ canopy cover. Ansley et al. (2004) found on a clay loam site near the current study site that, in the absence of grazing, $\mathrm{C}_{4}$ midgrass production declined sharply once mesquite cover exceeded $25 \%$. Similar results have been found by others (Scifres et al. 1982; East and Felker 1993; Teague et al. 2008a). Thus, although we did not achieve the degree of mesquite suppression planned, the firebased strategies slowed the rate of increase in mesquite cover and this had significant benefits regarding ecosystem restoration (Teague et al. 2010).

The second major finding was that there was a different response to the fire treatments on the different soil types. The $60 \%$ increase in mesquite cover in $5 \mathrm{yr}$ on the clay loam sites in the CU strategy represented an increase of 13.3 percentage units $(22.3 \%$ to $35.6 \%)$, or 2.7 percentage units $\cdot \mathrm{yr}^{-1}$. This rate of increase is similar to the 2.2 percentage units $\cdot \mathrm{yr}^{-1}$ that Ansley et al. (2001) found over a 20-yr period on similar soils near the current study area. The scaled increase in mesquite cover of $34 \%$ in the CU strategy (Fig. 7) was lower than the $60 \%$ increase found on clay loam soils because of the high percentage of shallow clay soils in both $\mathrm{CU}$ strategy replicates. There was no significant increase in mesquite cover on the shallow soil type during the 5 -yr period.

It was not as critical to apply fire on shallow soils for two reasons. First, mesquite encroachment rates were not as rapid on this soil type as on clay loam soils. Second, herbaceous production was not as great on shallow soils as on clay loam soils (Teague et al. 2008a). However, when fire was applied to shallow soils, in many cases, it seemed to have a long-term effect at reducing mesquite cover (see Figs. 3 and 4). This was probably because mesquite was smaller with lower base stem diameters that were more susceptible to fire.

The third major finding was that mesquite cover was reduced to a much greater degree in the fire and herbicide strategy than the two fire-only strategies. Mesquite response to the herbicide treatment was considered typical for an aerially applied mixture of clopyralid + triclopyr (Ansley et al. 2003; Mitchell et al. 2004). This treatment not only is effective at reducing mesquite cover to near zero but also root-kills $50-70 \%$ of the trees and thus reduces mesquite density (Mitchell et al. 2004; Ansley and Castellano 2006). Enhanced grass production following treatment can last at least $20 \mathrm{yr}$ (Ansley et al. 2004). A major advantage of the herbicide option is that, unlike prescribed fire, it requires very little preplanning and is not as dependent as is prescribed burning on long-term weather patterns. However, typical cost for this treatment is US $\$ 70-75 \cdot \mathrm{ha}^{-1}$ compared to $\$ 5-12 \cdot \mathrm{ha}^{-1}$ for fire, and it is not as economical as fire in the long-term if fire can be applied regularly (Teague et al. 2001, 2008b; Conner 2004). Fire is economical and can suppress mesquite under the right conditions. However, a top-killing fire transforms mesquite into multistemmed regrowth that can become a greater problem than before treatment if subsequent fires are not applied (Ansley and Jacoby 1998). For example, some of the 1996 fires in this study yielded high mesquite top-kill and likely reduced cover to near zero, yet by 2000 , there was no significant difference in cover than that found on the 1995 pretreatment images. Thus, even though cover was reduced to nearly zero the first year postfire, basal regrowth was so rapid that canopy cover, as viewed by aerial images, recovered within 5 yr postfire.

The fourth major finding is that the data indicate a significant relationship between herbaceous fine fuel, relative humidity, and air temperature and mesquite top-kill by fire. These three variables explained most of the variation $\left(R^{2}=0.93\right)$ associated with mesquite top-kill by fire. When these independent variables were analyzed separately, there were significant relationships between fine fuel and mesquite top-kill by fire $(P \leq 0.0001)$ and between relative humidity and mesquite top-kill by fire $(P \leq 0.0006)$, but there was no relationship between air temperature and top-kill or between wind speed and top-kill. However, when the five paddocks with fine fuel $>2700 \mathrm{~kg} \cdot \mathrm{ha}^{-1}$ were omitted, and regressions were limited to the remaining nine paddocks that had $<2100 \mathrm{~kg} \cdot \mathrm{ha}^{-1}$ of fine fuel, there was a significant $(P \leq 0.04)$ relationship between air temperature and top-kill. These results suggest that once a threshold of herbaceous fine fuel was attained, then effects of air temperature on mesquite top-kill by fire were marginalized, and fine fuel and $\mathrm{RH}$ became the driving variables. At lower fine fuel amounts, air temperature and possibly wind speed $(P=0.073)$ might play a more important role in affecting mesquite response to fire. 
Trollope and Tainton (1986) suggested that fine fuel amount was related to top-kill by fire of woody species in Africa. In west Texas, Britton and Wright (1971) found that fine fuel amount was a better predictor of mesquite mortality than were weather variables air temperature, $\mathrm{RH}$, and wind speed. In contrast, Ansley et al. (1998) found on a site near the current study site significant $(P<0.05)$ relationships between air temperature and mesquite top-kill by fire, fine fuel amount and top-kill by fire, and $\mathrm{RH}$ and top-kill by fire. Air temperature and fine fuel amount explained most of the variation $\left(R^{2}=0.83\right)$ associated with mesquite top-kill by fire. Thus, air temperature appeared to be a more important factor in Ansley et al.'s (1998) study than the results from the current study even though fine fuel amounts ranged from $1037 \mathrm{~kg}$. $\mathrm{ha}^{-1}$ to $5759 \mathrm{~kg} \cdot \mathrm{ha}^{-1}$.

Finally, the fifth major conclusion was that weather played a very significant role in our ability to suppress mature mesquite by prescribed fire. This study attempted to suppress mature mesquite with prescribed fire starting from a condition of a degraded herbaceous community that lacked the more productive $\mathrm{C}_{4}$ midgrasses. Data revealed that the most essential factor for maximizing mesquite top-kill was herbaceous fine fuel amount and other studies have found that mature mesquite usually are not top-killed unless there is at least 2000 $2500 \mathrm{~kg} \cdot \mathrm{ha}^{-1}$ fine fuel (Ansley et al. 1998). Without $\mathrm{C}_{4}$ midgrasses, our maximum level of fine fuel accumulation under optimal precipitation was in this range. Thus, we had little margin of error and untimely precipitation patterns often put conditions for achieving top-killing fires below optimum for two reasons. First, very little growing season precipitation from 1996-2000 limited grass growth to be used as fine fuel. Second, excessive precipitation during winter months accelerated $\mathrm{C}_{3}$ grass growth, which increased green tissue content of the fine fuel and reduced fire intensity. These factors limited not only frequency of burning, but also the intensity of the fires applied. The fire-only strategies likely would have been more effective at suppressing mesquite had precipitation been near average.

The herbicide portion of the study points to a more reasonable long-term approach for managing ranches infested by mature mesquite by using an expensive initial treatment such as herbicide sprays or mechanical treatments to kill or fell the mature mesquite and thus set up the site for repeated prescribed fires to maintain the treatment life of the expensive restoration treatments. Our goal of suppressing mature mesquite by only using rotational grazing and fire had limited success. Results reinforce the recommendation that mesquite cover should be no greater than $10 \%$ to $15 \%$ for fire to be effective, as outlined by Teague et al. (2003). Other, more expensive means of reducing brush are necessary when mesquite cover is greater. If fire is to be the main means of reducing mesquite brush, it also is important to reduce stocking rates by some $20 \%$ to ensure adequate fine fuel in most years (Teague et al. 2001).

\section{MANAGEMENT IMPLICATIONS}

This study suggests that rotational grazing in fenced paddocks could facilitate prescribed burning to slow encroachment of woody plants by providing a means to defer grazing and accumulate fine fuel for fire. The 8-paddock strategy allowed for greater flexibility than the 4-paddock strategy in managing livestock deferral and fine fuel for burning during drought periods. The study revealed that mesquite recovery after topkilling fires is rapid on clay loam soils that have the greatest potential for grass growth. Therefore a strategy that allows for repeated fires is essential once mesquite has been top-killed and physiognomy has been shifted to multistemmed basal regrowth. Finally, the most ideal use of fire in strategies dominated by mature woody plants such as mesquite might be as a second treatment following a more expensive restoration treatment involving herbicide spray or mechanical methods that kill or fell the mature trees. Realistically, if fire is to be the main means of reducing mesquite brush in this environment, brush cover must be less than $15 \%$ and low stocking rates must be used.

\section{ACKNOWLEDGMENTS}

The authors thank Tim Tunnell, Gerral Schulz, Steve Dowhower, Doug Tolleson, Scott Showers, Bob Cross, Matt Angerer, Jason Wrinkle, Jay Hunt, and Rob Borchardt, who assisted with the prescribed fires and/or cutting fire guards.

\section{LITERATURE CITED}

Ansley, R. J., and M. J. Castellano. 2006. Strategies for savanna restoration in the southern Great Plains: effects of fire and herbicides. Restoration Ecology 14:420-427.

Ansley, R. J., and P. W. Jacoby. 1998. Manipulation of fire intensity to achieve mesquite management goals in north Texas. In: T. L. Pruden and L. A. Brennan [EDS.]. Fire in ecosystem management: shifting the paradigm from suppression to prescription. Proceedings of the Tall Timbers Fire Ecology Conference No. 20; 7-10 May 1996; Boise, ID, USA. Lawrence, KS, USA: Allen Press. 20:195-204.

Ansley, R. J., D. L. Jones, T. R. Tunnell, B. A. Kramp, and P. W. Jacoby. 1998. Honey mesquite canopy responses to single winter fires: relation to fine fuel, weather and fire temperature. International Journal of Wildland Fire 8:241-252.

Ansley, R. J., B. A. Kramp, and D. L. Jones. 2003. Converting mesquite thickets to savanna through foliage modification with clopyralid. Journal of Range Management 56:72-80.

Ansley, R. J., W. E. Pinchak, W. R. Teague, B. A. Kramp, D. L. Jones, and P. W. Jacoby. 2004. Long-term grass yields following chemical control of honey mesquite. Journal of Range Management 57:49-57.

Ansley, R. J., H. T. Wiedemann, M. J. Castellano, and J. E. Slosser. 2006. Herbaceous restoration of juniper-dominated grasslands with chaining and fire. Rangeland Ecology and Management 59:171-178.

Ansley, R. J., X. B. Wu, and B. A. Kramp. 2001. Observation: long-term increases in mesquite canopy cover in a north Texas savanna. Journal of Range Management 54:171-176.

Archer, S., D. S. Schimel, and E. A. Holland. 1995. Mechanisms of shrubland expansion: land use, climate or $\mathrm{CO}_{2}$ ? Climatic Change 29:91-99.

Asner, G. P., S. R. Archer, R. F. Hughes, R. J. Ansley, and C. A. Wessman. 2003. Net changes in regional woody vegetation cover and carbon storage in Texas drylands, 1937-1999. Global Change Biology 9:316-335.

Bedunah, D. J., and R. E. Sosebee. 1984. Forage response of a mesquitebuffalograss community following range rehabilitation. Journal of Range Management 37:483-487.

Blackburn, W. H., and P. T. Tueller. 1970. Pinyon and juniper invasion in black sagebrush communities in east-central Nevada. Ecology 51:841-848.

Briske, D. D., J. D. Derner, J. R. Brown, S. D. Fuhlendorf, W. R. Teague, K. M. Havstad, R. L. Gillen, A. J. Ash, and W. D. Willms. 2008. Rotational 
grazing on rangelands: reconciliation of perception and experimental evidence. Rangeland Ecology and Management 61:3-17.

Britton, C. L., AND H. A. WriGHt. 1971. Correlation of weather and fuel variables to mesquite damage by fire. Journal of Range Management 24:136-141.

Canfield, R. H. 1941. Application of line interception in sampling range vegetation. Journal of Forestry 39:388-394.

Conner, J. R. 2004. Brush management-economic and financial considerations. In: W. T. Hamilton, A. McGinty, D. N. Ueckert, C. W. Hanselka, and M. R. Lee [EDS.]. Brush management-past, present and future. College Station, TX, USA: Texas A\&M University Press. p. 213-226.

Draper, N., ANd H. Smith. 1981. Applied regression analysis. 2nd ed. New York, NY, USA: John Wiley \& Sons. $709 \mathrm{p}$.

EAst, R. M., And P. Felker. 1993. Forage production and quality of 4 perennial grasses grown under and outside canopies of mature Prosopis glandulosa Torr. var. glandulosa (mesquite). Agroforestry Systems 22:91-110.

Freund, R. J., and R. C. Littell. 1981. SAS for linear models. Cary, NC, USA: SAS Institute Inc. $231 \mathrm{p}$.

Freund, R. J., AND R. C. LitTeLl. 1986. SAS system for regression. Cary, NC, USA: SAS Institute Inc. $164 \mathrm{p}$.

Fuhlendorf, S. D., AND D. M. Engle. 2004. Application of the fire-grazing interaction to restore a shifting mosaic on tallgrass prairie. Journal of Applied Ecology 41:604-614.

Kramp, B. A., R. J. Ansley, and T. R. Tunnell. 1998. Survival of mesquite seedlings emerging from cattle and wildlife feces in a semiarid grassland. The Southwestern Naturalist 43:300-312.

McGinty, A. 2004. Chemical weed and brush control—a Texas range scientist's viewpoint. In: W. T. Hamilton, A. McGinty, D. N. Ueckert, C. W. Hanselka, and M. R. Lee [EDS.]. Brush management-past, present and future. College Station, TX, USA: Texas A\&M University Press. p. 76-84.

Mitchell, R., S. Whisenant, and R. Sosebee. 2004. Chemical brush management-a paradigm shift. In: W. T. Hamilton, A. McGinty, D. N. Ueckert, C. W. Hanselka, and M. R. Lee [EDS.]. Brush management-past, present and future. College Station, TX, USA: Texas A\&M University Press. p. 67-75.

Pinchak, W. E., R. K. Heitschmidt, S. K. Canon, and S. L. Dowhower. 1990. Effect of long-term, year-long grazing at moderate and heavy rates of stocking on diet selection and forage intake dynamics. Journal of Range Management 43:304-309.

Pinchak, W. E., W. R. Teague, R. J. Ansley, J. A. Waggoner, and S. L. Dowhower. 2010. Integrated grazing and prescribed fire restoration strategies in a mesquite savanna: III. Cow-calf production responses. Rangeland Ecology and Management 63:298-307.

SAS [computer program]. 2002. SAS Version 9.1 for Windows. Cary, NC, USA: SAS Institute, Inc.

SCIFRES, C. J. 1980. Brush management-principles and practices for Texas and the southwest. College Station, TX, USA: Texas A\&M University Press. $360 \mathrm{p}$.

Scifres, C. J., and W. T. Hamilton. 1993. Prescribed burning for brushland management: the south Texas example. College Station, TX, USA: Texas A\&M University Press. 246 p.
Scifres, C. J., J. L. Mutz, R. E. Whitson, and D. L. Drawe. 1982. Interrelationships of huisache canopy cover with range forage on the coastal prairie. Journal of Range Management 35:558-562.

Teague, W. R., R. J. Ansley, U. P. Kreuter, W. E. Pinchak, and J. M. McGrann. 2001. Economics of managing mesquite in north Texas: a sensitivity analysis. Journal of Range Management 54:553-560.

Teague, W. R., R. J. Ansley, W. E. Pinchak, S. L. Dowhower, S. A. Gerrard, and J. A. Waggoner. 2008a. Interannual herbaceous biomass response to increasing honey mesquite cover on two soils. Rangeland Ecology and Management 61:496-508.

Teague, R., R. Borchart, J. Ansley, B. Pinchak, J. Cox, J. Foy, and J. McGrann. 1997. Sustainable management strategies for mesquite rangeland: the Waggoner Kite project. Rangelands 19:4-8.

Teague, W. R., and S. L. Dowhower. 2003. Patch dynamics under rotational and continuous grazing management in large, heterogeneous paddocks. Journal of Arid Environments 53:211-229.

Teague, W. R., S. L. Dowhower, R. J. Ansley, W. E. Pinchak, and J. A. Waggoner. 2010. Integrated grazing and prescribed fire restoration strategies in a mesquite savanna: I. Vegetation responses. Rangeland Ecology and Management 63:275-285.

Teague, W. R., W. E. Grant, U. P. Kreuter, H. Diaz-Solis, S. Dube, M. M. Kothmann, W. E. Pinchak, and R. J. Ansley. 2008b. An ecological economic simulation model for assessing fire and grazing management effects on mesquite rangelands in Texas. Ecological Economics 64:612-625.

Teague, W. R., U. P. Kreuter, R. J. Ansley, and J. M. McGrann. 2003. Economics of fire as a follow-up to herbicide treatment of mesquite. In: N. Allsopp, A. R. Palmer, S. J. Milton, K. P. Kirkman, I. H. Kerley, C. R. Hurt, and C. J. Brown [EDS.]. Rangelands in the new millennium. Proceedings of the 7th International Rangeland Congress; 26 July-1 August 2003; Durban, South Africa. Irene, South Africa: Document Transfer Technologies. p. 1973-1975. Available at: http://www.rangelandcongress.com/Papers/222.pdf. Accessed 24 March 2010.

Trollope, W. S. W., and N. M. Tainton. 1986. Effect of fire intensity on the grass and bush components of the Eastern Cape Thornveld. Journal of the Grassland Society of Southern Africa 3:37-42.

us Department of Agriculture-Natural Resources Conservation Service. 2009. Plants Database. Available at: http://plants.usda.gov. Accessed 28 January 2009.

uS Department of Agriculture-Soll Conservation Service. 1962. Soil survey of Wilbarger County, Texas. Soil Survey Series 1959, No. 18. Fort Worth, TX, USA: USDA Soil Conservation Service. 64 p.

Van Auken, O. W. 2000. Shrub invasions of North American semiarid grasslands. Annual Review of Ecology and Systematics 31:197-215.

Walker, J., J. A. Robertson, and L. K. Penridge. 1986. Herbage response to tree thinning in a Eucalyptus crebra woodland. Australian Journal of Ecology 11:135-140.

Wright, H. A., and A. W. Balley. 1982. Fire ecology. New York, NY, USA: John Wiley \& Sons. 501 p. 